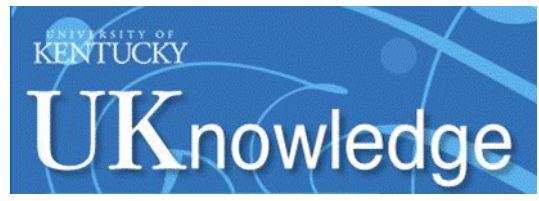

University of Kentucky UKnowledge

$12-2009$

\title{
Manganese Flux across the Blood-Brain Barrier
}

Robert A. Yokel

University of Kentucky, ryokel@email.uky.edu

Right click to open a feedback form in a new tab to let us know how this document benefits you.

Follow this and additional works at: https://uknowledge.uky.edu/ps_facpub

Part of the Pharmacy and Pharmaceutical Sciences Commons 


\section{Manganese Flux across the Blood-Brain Barrier}

Digital Object Identifier (DOI)

https://doi.org/10.1007/s12017-009-8101-2

Notes/Citation Information

Published in NeuroMolecular Medicine, v. 11, issue 4.

Copyright $\odot$ 2009, Humana Press Inc.

The copyright holder has granted the permission for posting the article here.

The document available for download is the authors' post-peer-review final draft of the article.

This review is available at UKnowledge: https://uknowledge.uky.edu/ps_facpub/189 
Manganese flux across the blood-brain barrier

Robert A. Yokel ${ }^{a, b}$

${ }^{a}$ Department of Pharmaceutical Sciences, College of Pharmacy, University of Kentucky

Academic Medical Center, 725 Rose Street, Lexington, KY 40536-0082, USA, ${ }^{b}$ Graduate Center

for Toxicology, University of Kentucky Academic Medical Center, Lexington, KY 40536-0082, USA

Robert A. Yokel, Ph.D.

511C Pharmacy Building

725 Rose Street

University of Kentucky Academic Medical Center

Lexington, KY40536-0082

phone: 859-257-4855

fax: 859-323-6886

e-mail: ryokel@email.uky.edu

Running title: Blood-brain barrier manganese flux 


\section{Abbreviations:}

\begin{tabular}{|c|c|c|}
\hline BBB & - & blood-brain barrier \\
\hline BMEC & - & brain microvascular endothelial cell \\
\hline$D_{o / a}$ & - & octanol/aqueous partitioning coefficient \\
\hline$J$ & - & influx \\
\hline $\mathrm{K}_{\mathrm{d}}$ & - & diffusion constant \\
\hline $\mathrm{K}_{\mathrm{el}}$ & - & apparent elimination rate constant \\
\hline $\mathrm{K}_{\text {in }}$ & - & influx transfer coefficient \\
\hline $\mathrm{K}_{\mathrm{m}}$ & - & Michaelis-Menten constant \\
\hline $\mathrm{K}_{\text {out }}$ & - & brain capillary efflux \\
\hline MMT & - & methylcyclopentadienyl manganese tricarbonyl \\
\hline $\mathrm{Mn}$ & - & manganese \\
\hline MW & - & molecular weight \\
\hline$P_{\text {diffusion }}$ & - & estimated permeability due to diffusion \\
\hline PS & - & permeability-surface area product \\
\hline S & - & surface area of rat brain capillaries \\
\hline Tf & - & transferrin \\
\hline TfR-ME & & transferrin receptor mediated endocytosis \\
\hline$V_{\text {brain }}$ & - & brain distribution volume \\
\hline$V_{\max }$ & - & maximum velocity of carrier-mediated transport \\
\hline
\end{tabular}




\begin{abstract}
:
Manganese $(\mathrm{Mn})$ is essential for brain growth and metabolism, but in excess can be a neurotoxicant. The chemical form (species) of Mn influences its kinetics and toxicity. Significant Mn species entering the brain are the $\mathrm{Mn}^{2+}$ ion and $\mathrm{Mn}$ citrate which, along with $\mathrm{Mn}$ transferrin, enter the brain by carrier-mediated processes. Although the divalent metal transporter (DMT-1) was suggested to be a candidate for brain Mn uptake, brain Mn influx was not different in Belgrade rats, which do not express functional DMT-1, compared to controls. Brain Mn influx was not sodium dependent or dependent on ATP hydrolysis, but was reduced by mitochondrial energy inhibitors. Mn and Fe do not appear to compete for brain uptake. Brain Mn uptake appears to be mediated by a Ca uptake mechanism, thought to not be a p-type ATPase, but a store-operated calcium channel. Efflux of Mn from the brain was found to be slower than markers used as membrane impermeable reference compounds, suggesting diffusion mediates brain Mn efflux. Owing to carrier-mediated brain Mn influx and diffusion-mediated efflux, slow brain Mn clearance and brain Mn accumulation with repeated excess exposure would be predicted, and have been reported. This may render the brain susceptible to $\mathrm{Mn}$-induced neurotoxicity from excessive $\mathrm{Mn}$ exposure.
\end{abstract}

Index Entries: Blood-brain barrier, brain efflux, brain influx, calcium, in situ brain perfusion, in vitro, iron, manganese, parkinsonism, rat 


\section{Manganese is an essential trace element that can be a neurotoxicant}

Manganese $(\mathrm{Mn})$ is an essential trace element for normal brain development and function. It is a cofactor for glial-specific glutamine synthetase (that accounts for $80 \%$ its brain concentration), superoxide dismutase, pyruvate carboxylase and other enzymes.

Manganese can also be a neurotoxicant. This has been reported in workers involved in mining and grinding manganese dioxide, dry-cell battery production, ferromanganese smelting, Mn oxide and salt production, and Mn welding (Chandra et al. 1981; Huang et al. 1989; Ono et al. 2002;

Roels et al. 1987; Roels et al. 1992; Sjögren et al. 1990; Sjögren et al. 1996). Neurotoxicity has also been associated with exposure to Mn-containing fungicides (e.g., maneb) (Ferraz et al. 1988), drinking well water contaminated by buried dry cell batteries (Kawamura et al. 1941), and in patients who received Mn-containing medical diagnostic contrast agents (e.g., mangafodipir) and long-term parenteral nutrition (Nagatomo et al. 1999). Other Mn exposures include fertilizers, electronics and the fuel additive methylcyclopentadienyl manganese tricarbonyl (MMT) (Hudnell 1999). Symptoms of manganism include asthenia, adynamia, sialorrhea, fatigability, cephalalgia, sleep disturbances, muscular pain and hypertonia, mask-like face, gait changes, reduced coordination, hallucinations, and mental irritability.

\section{The chemical form (species) of Mn can influence its kinetics and toxicity}

The chemical form (species) of metals may influence their absorption, distribution and toxicity (Yokel et al. 2006). Greater brain $\mathrm{Mn}$ concentrations were seen after $\mathrm{MnCl}_{2}$ than $\mathrm{MMT}$ or $\mathrm{Mn}$ oxide (Gianutsos et al. 1985). Higher striatal Mn concentrations were seen after oral and intratracheal, but not intraperitoneal, $\mathrm{MnCl}_{2}$ than $\mathrm{MnO}_{2}$ (Roels et al. 1997). More rapid brain uptake resulted from soluble Mn chloride or sulfate than insoluble Mn oxide or phosphate (Dorman et al. 2001a; Drown et al. 1986). 
In biological environments $\mathrm{Mn}$ most commonly exists as $\mathrm{Mn}^{2+}$, which is stable in aqueous solutions up to $\mathrm{pH} \sim 7.5$, and $\mathrm{Mn}^{3+}$, which is unstable in aqueous solutions $>\mathrm{pH} 2$ and can undergo disproportionation to $\mathrm{Mn}^{2+}$ and $\mathrm{Mn}^{4}$ unless stabilized as a complex with a ligand. After absorption some $\mathrm{Mn}^{2+}$ oxidizes to $\mathrm{Mn}^{3+}$ in blood in 1 to 5 hours (Jursa and Smith 2009; Scheuhammer and Cherian 1985). Ultrafiltration of rat serum suggested $>70 \%$ of the $\mathrm{Mn}$ was protein bound (Rabin et al. 1993). Predominant serum $\mathrm{Mn}^{2+}$ species were calculated to be albumin-bound (84\%), a hexahydrated ion (6.4\%), 1:1 complexes with bicarbonate (5.8\%) and citrate (2.0\%), and 1\% Mn transferrin (Tf) (Harris and Chen 1994). Size exclusion chromatography suggested $55 \%$ of serum Mn was bound to albumin or Tf and $30 \%$ to low MW species, of which 3.5 and $94 \%$ were Mn citrate and inorganic Mn (Nischwitz et al. 2008). Albumin does not cross the intact blood-brain barrier (BBB). The 1:1 Mn:citrate complex involves coordination bonds between Mn and the central hydroxyl group and the two terminal carboxylates. The central carboxylate group, which is not involved in this complex (Amico and Daniele 1979), may serve as a recognition moiety for a transporter.

$\mathrm{Mn}^{3+}$ is quite reactive, rapidly associating with $\mathrm{Tf}$, whereas $\mathrm{Mn}^{2+}$ does not (Aisen et al. 1969). It is expected that all $\mathrm{Mn}^{3+}$ in plasma is bound to $\mathrm{Tf}$, but it is not known what percent of total plasma $\mathrm{Mn}$ is $\mathrm{Mn}^{3+}$. With a MW of $\sim 77,000 \mathrm{D}_{\mathrm{a}}$, Tf would not be expected to cross membranes in the absence of a carrier. Tf-receptor mediated endocytosis (TRf-ME) is expressed by the brain microvascular endothelial cell (BMECs) of the BBB (Jefferies et al. 1984), potentially enabling Mn to cross the BBB. Based on the Mn species in blood plasma, candidates for brain Mn uptake are the hydrated $\mathrm{Mn}^{2+}$ ion, $\mathrm{Mn}\left(\mathrm{HCO}_{3}\right)_{2}, \mathrm{Mn}$ citrate and $\mathrm{Mn} \mathrm{Tf}$. 
$\mathrm{Mn}^{2+}$ and $\mathrm{Mn}^{3+}$ have different toxicities (Reaney et al. 2002). Extensive studies have failed to positively identify $\mathrm{Mn}^{3+}$ in the mitochondria of PC12 or human neuroteratocarcinoma (NT2) cells, brain, liver or heart, suggesting $\mathrm{Mn}^{2+}$ may be the toxic species (Gunter et al. 2006).

Relevant to Mn efflux from brain to blood, Tf probably does not play a significant role. The concentration of $\mathrm{Tf}$ in brain extracellular fluid is $<0.25 \mu \mathrm{M}$. The Tf metal binding sites may all be occupied by Fe, leaving none available for Mn binding (Bradbury 1997). Most Mn in brain extracellular fluid is a low MW species, probably Mn citrate (Michalke et al. 2007).

The kinetics of $\mathrm{Mn}$ re-speciation may influence the availability of $\mathrm{Mn}$ species for distribution into or out of the brain. The rate of formation of a Mn chelate complex, such as Mn citrate, should be about $10^{+6} \mathrm{~s}^{-1}$, based on the rate of water exchange for $\mathrm{Mn}^{2+}\left(\sim 10^{+7} \mathrm{~s}^{-1}\right)$ (Burgess 1992). The rates of binding of other ligands with metals are usually within a factor of ten of the water exchange rate. The rate that $\mathrm{Mn}$ might exchange a ligand, such as citrate, for another, can be calculated from $\mathrm{K}_{\text {eq }}$ $=\mathrm{K}_{\mathrm{on}} / \mathrm{K}_{\mathrm{off}}$, where $\mathrm{K}_{\text {eq }}(\log \mathrm{K})$ is the equilibrium constant, and $\mathrm{K}_{\mathrm{on}}$ and $\mathrm{K}_{\mathrm{off}}$ are the metal binding association and dissociation constants. For Mn citrate, with a $\mathrm{K}_{\mathrm{eq}}$ of $\sim 4$ (Petti and Powell 1997) and $\mathrm{K}_{\mathrm{on}} \sim 10^{6} \mathrm{~s}^{-1}$, $\mathrm{K}_{\text {off }}$ will be $100 \mathrm{~s}^{-1}$. For an exchange reaction involving $\mathrm{Mn}$ and ligands with comparable $\mathrm{K}_{\text {eq }}$ values, the approach to equilibrium will be a first-order process with a rate constant equal to the sum of the two ligand exchange times (Moore and Pearson 1981), or $\sim 200$ $\mathrm{s}^{-1}$. This corresponds to a half-life $\left(t_{1 / 2}\right)$ of $3 \mathrm{msec}$. The complete reaction would occur in $\sim 5$ to 6 $\mathrm{t}_{1 / 2} \mathrm{~S}$, or $\sim 20 \mathrm{msec}$. Therefore equilibrium among the $\mathrm{Mn}^{2+}$ ion and $\mathrm{Mn}$ complexes with citrate and other common ligands in blood plasma should occur within seconds. After oral or intravenous $\mathrm{MnCl}_{2}$ administration nearly all of the $\mathrm{Mn}$ was associated with $\mathrm{Tf}$ after $30 \mathrm{~min}$, suggesting $\mathrm{Mn} \mathrm{Tf}$ is the predominant species of $\mathrm{Mn}$ in blood plasma (Davidsson et al. 1989). 


\section{Mn can enter the brain via several routes}

Brain Mn entry is primarily a result of exchange between blood plasma and brain tissue. Mn can enter the brain from blood plasma by crossing the BMECs into the brain, crossing the choroid plexuses into cerebrospinal fluid and then into the brain, and uptake by the olfactory and trigeminal nerves directly into the brain. This review focuses on the BBB route of brain Mn exchange.

The BBB is a highly restrictive membrane. The anatomical basis includes the tight junctions between BMECs, a basement membrane of collagen and collagen-like protein, pericytes that surround $\sim 30 \%$ of the BMECs, and astrocyte foot processes that surrounded $\sim 98 \%$ of this complex. The BMECs comprise $\sim 0.1 \%$ of the total volume of the brain (Pardridge 2003 ).

\section{Mn can enter the brain across the blood-brain barrier}

Some $\mathrm{Mn}$ species have been shown to enter the brain. Intra-carotid injection of $\mathrm{MnCl}_{2}$ with ${ }^{14} \mathrm{C}$ sucrose (as a marker of cerebrovascular space) and ${ }^{3} \mathrm{H}_{2} \mathrm{O}$ (which can enter the brain during a single pass) to rats followed by decapitation after $15 \mathrm{~s}$ (single pass of injected solution through the brain) indicated saturable brain Mn uptake (Aschner and Gannon 1994). No difference in brain Mn uptake was seen when Tf was added to the Mn and the mixture immediately injected into the carotid artery. Incubation of Mn with Tf for up to 5 days increased brain Mn uptake (Aschner and Gannon 1994), suggesting oxidation of $\mathrm{Mn}^{2+}$ to $\mathrm{Mn}^{3+}$ over time, $\mathrm{Mn}^{3+}$ complexation with $\mathrm{Tf}$, and Mn Tf brain uptake via TfR-ME. These results suggested brain uptake of two Mn species, Mn Tf and perhaps the $\mathrm{Mn}^{2+}$ ion. In rats given an iv infusion of $\mathrm{MnCl}_{2}$ to achieve a steady-state arterial blood plasma Mn concentration, the brain Mn transfer coefficient decreased as Mn concentration increased from 0.08 to $78 \mu \mathrm{M}$, demonstrating both saturable and non-saturable components (Murphy et al. 1991). Mn uptake into sciatic nerve was similarly mediated by facilitative, saturable 
process(es) (Wadhwani et al. 1992). Noting that the transfer coefficient for $0.08 \mu \mathrm{M}$ Mn in plasma was more than 2 orders of magnitude greater than reported for TfR-ME of Fe and $\mathrm{Ga}$, the authors concluded that non-protein-bound $\mathrm{Mn}^{2+}$ would be the predominate species that crosses the $\mathrm{BBB}$, even if it was only $1 \%$ of total plasma Mn. In these studies the Mn ion mixed with blood before it entered the brain, so it may have crossed the BBB associated with a ligand from blood plasma. The Michealis-Menten constant $\left(\mathrm{K}_{\mathrm{m}}\right)$ of Mn influx into the brain was $\sim 1 \mu \mathrm{M}$ (Murphy et al. 1991).

The use of radioisotopic $\mathrm{Mn}\left({ }^{54} \mathrm{Mn}\right)$ at concentrations below the $\mathrm{K}_{\mathrm{m}}$ enables the conduct of studies at physiologically-relevant Mn concentrations, and assures that measured $\mathrm{Mn}$ is due to the administration of the ${ }^{54} \mathrm{Mn}$ test dose. ${ }^{54} \mathrm{Mn}$ was used as a tracer in most of the above and following studies.

Control over the chemical composition of the fluid flowing through the brain can be accomplished using the in situ brain perfusion technique. A perfusate introduced into a carotid artery is delivered to the brain at a rate sufficient to prevent entry of collateral blood circulation into the perfused hemisphere (Takasato et al. 1984). This technique was used to study $\mathrm{MnCl}_{2}$ brain uptake from bicarbonate-buffered plasma electrolyte solution, plasma/serum and whole blood perfusates (Rabin et al. 1993). Brain uptake was reported as influx clearance $\left(K_{i n}\right)$, a measure of clearance from blood into a single brain compartment containing endothelial cells, brain cells and brain interstitial space. $\mathrm{K}_{\mathrm{in}}$, the quotient of uptake space and time, is a measure of the rate of influx of a substance in a given time into a given amount (space) of brain. It reflects the volume of perfusate cleared of substrate which is transferred into mass of brain over a given time period. The $\mathrm{Mn} \mathrm{K}_{\text {in }}$ from blood and plasma was several-fold less than from the electrolyte solution. Addition of albumin, $\mathrm{Tf}$ and $\mathrm{\alpha}_{2}$-macroglobulin to an electrolyte solution reduced brain $\mathrm{Mn} \mathrm{K}_{\text {in }}$ several fold, suggesting the Mn ion entered the brain more rapidly than plasma-protein-bound $\mathrm{Mn}$ species. It is 
known that TfR-ME is quite slow, $2.5 \mathrm{Fe}$ molecules/receptor/min (Cole and Glass 1983). These results, and the results of (Aschner and Gannon 1994), who found an increase of brain uptake of Mn incubated with Tf, are not in agreement.

There was no difference in brain $\mathrm{Mn} 1 \mathrm{~h}$ after iv injection of $\mathrm{Mn}$ in $\mathrm{pH} 7.4$ or 8.6 vehicle, but less brain $\mathrm{Mn}$ was seen after 6 days from the $\mathrm{pH} 8.6$ than 7.4 vehicle and even less when the Mn was Tf bound (Takeda et al. 2000). The difference between the $\mathrm{pH} 7.4$ and 8.6 vehicles is difficult to understand in light of the buffering ability of blood. The authors suggested Tf-independent brain Mn uptake for a short period. This is supported by observations of no difference in brain Mn in hypotransferrinemic compared to normal mice after iv Mn injection (Dickinson et al. 1996; Malecki et al. 1999).

\section{Brain Mn uptake is carrier-mediated}

Mn citrate is another plasma Mn species that is a candidate for brain uptake. To assess $\mathrm{Mn}$ citrate, and further study $\mathrm{Mn}^{2+}$ ion and $\mathrm{Mn} \mathrm{Tf}$, flux across the BBB, the in situ brain perfusion technique was used to determine their $\mathrm{K}_{\text {in }}$ values. These are two representative unbound, small ligand-complexed, and a plasma protein-bound, Mn species. To determine if their brain uptake rates were diffusion or carrier mediated, the $\mathrm{K}_{\text {in }}$ of each $\mathrm{Mn}$ species was compared to its estimated rat brain cerebral capillary diffusion rate. This was estimated based on the relationship between MW and the octanol/aqueous partitioning coefficient $\left(D_{o / a}\right)$ (Levin 1980). The permeability $\times$ surface area product $\left(\mathrm{P}_{\text {diffusion }} \mathrm{S}\right)$ was then calculated from the product of diffusion and rat brain capillary surface area $\left(240 \mathrm{~cm}^{2} / \mathrm{g}\right)$ as described (Smith 1989). $P_{\text {diffusion }} \mathrm{S}$ has the same units as $\mathrm{K}_{\text {in }}$ and $\mathrm{K}_{\text {out }}(\mathrm{ml} / \mathrm{s} / \mathrm{g}$ brain), measures of influx and efflux at the BBB, respectively. 
The calculated rat brain capillary diffusion rates of these $3 \mathrm{Mn}$ species, sucrose and dextran are shown in Table 1. The $\mathrm{P}_{\text {diffusion }} \mathrm{S}$ values for the $3 \mathrm{Mn}$ species, sucrose and dextran were similar and very small, suggesting diffusion of all $3 \mathrm{Mn}$ species through the BBB would be very slow. In fact, sucrose and dextran would be expected to diffuse more rapidly through the BBB than the $\mathrm{Mn}^{2+}$ ion and $\mathrm{Mn}$ citrate in the absence of a carrier.

\section{Table 1 goes about here}

The $\mathrm{K}_{\text {in }}$ values of the $\mathrm{Mn}^{2+}$ ion, $\mathrm{Mn}$ citrate, and $\mathrm{Mn}$ Tf were determined by in situ brain perfusion in nine brain regions (frontal, parietal and occipital cortex; cerebellum; caudate; hippocampus; thalamus/hypothalamus; midbrain/colliculus; and pons/medulla). They ranged from 5 to 13,3 to 51 , and 2 to $13 \times 10^{-5} \mathrm{ml} / \mathrm{s} / \mathrm{g}$, respectively. The $\mathrm{K}_{\text {in }}$ for $\mathrm{Mn}$ ion influx exceeded that predicted for diffusion in the parietal cortex and hippocampus, but not caudate; for $\mathrm{Mn}$ citrate the $\mathrm{K}_{\text {in }}$ exceeded that predicted for diffusion in 6 brain regions, including the caudate (Crossgrove et al. 2003). As the caudate is part of the basal ganglia, which is involved in manganism and a site of Mn accumulation in those conditions, the results suggest carrier-mediated Mn citrate uptake may contribute to $\mathrm{Mn}$ accumulation. A significantly greater $\mathrm{K}_{\text {in }}$ than the calculated diffusion rate suggests carrier-mediated processes enable brain Mn uptake. Within a given brain region, the $\mathrm{K}_{\text {in }}$ of $\mathrm{Mn}$ citrate was generally higher than $\mathrm{Mn} \mathrm{Tf}$ and the $\mathrm{Mn}^{2+}$ ion (Crossgrove et al. 2003; Murphy et al. 1991; Rabin et al. 1993). As noted above, thermodynamic modeling suggests $40 \%$ of the Mn available to cross the BBB is the $\mathrm{Mn}^{2+}$ ion, while $\sim 15 \%$ is Mn citrate. With one-third the concentration and with an uptake rate three times faster, Mn citrate brain influx would be comparable to the $\mathrm{Mn}^{2+}$ ion, suggesting it is a major $\mathrm{Mn}$ species that enters the brain. For the $\mathrm{Mn}$ Tf species, the finding of no difference in brain Mn in hypotransferrinemic compared to normal 
mice after iv $\mathrm{Mn}$ injection suggests it does not play a major role in brain Mn uptake (Dickinson et al. 1996; Malecki et al. 1999).

The $\mathrm{K}_{\text {in }}$ of the $\mathrm{Mn}^{2+}$ ion and $\mathrm{Mn}$ citrate decreased in the presence of increasing, and very large, amounts of the $\mathrm{Mn}^{2+}$ ion and $\mathrm{Mn}$ citrate, respectively, although not in a concentration-dependent manner (Crossgrove et al. 2003). This is consistent with a non-saturable component of Mn uptake from blood (Murphy et al. 1991). The flow rate dependency of the $\mathrm{Mn}^{2+}$ ion influx rate was determined because flow-rate dependent uptake is a property of some carrier-mediated uptake systems, but not diffusion. Brain $\mathrm{Mn} \mathrm{K}_{\text {in }}$ was not different at brain perfusion rates of 10 compared to $20 \mathrm{ml} / \mathrm{min}$, showing $\mathrm{Mn}$ brain uptake was not rapid enough to be limited by the rate of perfusate flow thorough the brain (Crossgrove et al. 2003).

Influx ( $\mathrm{J}$; velocity of brain uptake) was calculated as the product of PS and Mn concentration. Mean $J$ vs. Mn concentration was plotted and fit to kinetic models involving 0, 1 and 2 MichaelisMenten terms (below), where $J_{0}, J_{1}$ and $J_{2}$ represent fits of the same $J$ data set, $K_{d}$ is the diffusion constant, $\mathrm{C}$ is total $\mathrm{Mn}$ concentration, $\mathrm{V}_{\max }$ is the maximum velocity of the putative transporter(s), $\mathrm{K}_{\mathrm{m}}$ is the Michaelis-Menten constant of saturable uptake, and $\mathrm{K}_{d}{ }^{*} \mathrm{C}$ represents the non-saturable component(s) of uptake. Sucrose and dextran were included in the calculations for comparison since they were used as vascular markers that exhibit poor membrane permeability, crossing the BBB by diffusion.

$$
\begin{aligned}
& J_{0}=\mathrm{K}_{d}{ }^{*} \mathrm{C} \\
& J_{1}=\mathrm{V}_{\max }{ }^{*} \mathrm{C} /\left[\mathrm{K}_{\mathrm{m}}+\mathrm{C}\right]+\mathrm{K}_{\mathrm{d}}{ }^{*} \mathrm{C} \\
& J_{2}=\mathrm{V}_{\max 2}{ }^{*} \mathrm{C} /\left[\mathrm{K}_{\mathrm{m} 2}+\mathrm{C}\right]+\mathrm{V}_{\max }{ }^{*} \mathrm{C} /\left[\mathrm{K}_{\mathrm{m}}+\mathrm{C}\right]+\mathrm{K}_{\mathrm{d}}{ }^{*} \mathrm{C}
\end{aligned}
$$

Seven of $9 \mathrm{Mn}$ citrate-treated (including caudate) and 2 of $9 \mathrm{Mn}^{2+}$ ion-treated brain regions (caudate and thalamus/hypothalamus) were best fit by $J_{1}$. The remaining regions were best fit by 
$J_{0}$, the diffusion-only model of brain Mn uptake. These results provided further evidence of carriermediated brain $\mathrm{Mn}$ influx of the $\mathrm{Mn}^{2+}$ ion and $\mathrm{Mn}$ citrate (Crossgrove et al. 2003). It is noteworthy that the caudate, one of the brain regions involved in manganism, showed evidence of nondiffusional $\mathrm{Mn}$ uptake of both the $\mathrm{Mn}^{2+}$ ion and $\mathrm{Mn}$ citrate and a $\mathrm{K}_{\text {in }}$ for $\mathrm{Mn}$ citrate influx that exceeded the prediction for diffusion (above).

$\mathrm{Mn}^{2+}$ ion uptake into BMECs was temperature dependent from 4 to $37^{\circ} \mathrm{C}$. Uptake was plotted against temperature to generate the activation energy from the Århenius equation, which was 27 $\mathrm{kJ} / \mathrm{mol}$. This is consistent with values reported for ion channels (18-34 kJ/mol) (Liu and Ambudkar 2001).

Further evidence of carrier-mediated uptake of Mn citrate was obtained from its rate of uptake into immortalized murine brain endothelial-derived b.End5 cells. Uptake normalized to cell volume, assumed to be $2 \mu / \mathrm{mg}$ protein (Edlund and Halestrap 1988), showed intracellular Mn citrate was $\sim$ 10-fold greater than predicted by diffusion (Yokel and Crossgrove 2004).

\section{Manganese is transported across several non-blood-brain-barrier membranes}

The above results suggest brain influx of the $\mathrm{Mn}^{2+}$ ion, Mn citrate and $\mathrm{Mn}$ Tf are carrier-mediated processes. Mn flux across other membranes is carrier mediated. There is likely to be active $\mathrm{Mn}$ transport by the liver into bile. The carrier has not been identified (Schramm and Brandt 1986) other than its independence from glutathione (Sugawara et al. 1994); Curtis Klaassen, personal communication). Manganese is actively transported into and out of astrocytes. Although the transporter(s) has not been identified, efflux was stimulated by $\mathrm{MnCl}_{2}$ introduction into the cell medium suggesting trans-stimulation, "consistent with efflux and influx mediated by the same system" (Aschner et al. 1992). Ferret and human erythrocyte Mn uptake was thought to be 
mediated by the $\mathrm{Na} / \mathrm{Ca}$ exchanger and Ca channels, respectively (Frame and Milanick 1991; Lucaciu et al. 1997). Mn flux across Caco-2 cells was much faster from the apical than basolateral side (Leblondel and Allain 1999). The authors found evidence for temperature dependence, competition of Mn uptake by $\mathrm{Ca}$, inhibition by Ca channel blockers, Na-dependence, and ATP-independence, concluding that $\mathrm{Mn}$ uptake from the gastrointestinal tract may by mediated by the same type channel as involved in Ca uptake. Transporters mediating Mn flux across some of these non-BBB membranes have been identified, including Ca channels at presynaptic nerve endings and motor nerve terminals, a Na/Mg anti-porter in erythrocytes, and an active Ca uniporter in mitochondria (Takeda 2003). Owing to the essential nature of $\mathrm{Mn}$, it is not surprising that it distributes across the placenta into umbilical cord blood and into the fetus; and is excreted in breast milk, absorbed and appears in suckling offspring organs (Miller et al. 1987; Nishimura and Inaba 1983; Onoda et al. 1978; Rossipal 2000; Tsukamoto et al. 1987). Placental transfer seems to increase in the latter stages of gestation (Onoda et al. 1978; Tsukamoto et al. 1987). Although the TfR and DMT-1 are expressed in human placenta (Chong et al. 2005;

Georgieff et al. 2000; Leong and Lonnerdal 2005; Vandewalle et al. 1985), there are no reports that identify the mechanism(s) of Mn transport across the placenta or mammary epithelial cells. These sites and mechanisms of Mn transport across membranes, and those discussed below, are shown in Figure 1.

\section{Mechanisms mediating brain Mn influx}

There was no significant increase of brain $\mathrm{Mn}$ in humans from pre-mature infants to aged adults. This suggests the brain has an efficient homeostatic mechanism for normal Mn exposure (Markesbery et al. 1984). 
Considering both the essentiality of $\mathrm{Mn}$ in the brain and its potential to damage the brain when present in excess, one might expect $\mathrm{Mn}$ brain influx and efflux to be carrier mediated, as all organisms have systems for the export of toxic cations (Ketchum 1999). There are numerous facilitative diffusion carriers and active transporters at the BBB (Yokel 2006). However, not all BBB carriers have been identified. It was estimated that only $\sim 50 \%$ of the functional BBB transporters had been discovered (Pardridge 2003).

\section{The hypothesis that DMT-1 mediates brain Mn uptake}

One of the BBB carriers is the divalent metal (cation) transporter DMT-1 (aka: DCT-1, Nramp2, and SLC11A2). It is a high affinity, non-transferrin-bound, membrane transporter with nonselective affinity for divalent cations, including $\mathrm{Mn}^{2+}$ (Gunshin et al. 1997). $\mathrm{Mn}^{2+}$ was a substrate at pH 5.5 when DMT-1 was transfected into oocytes (Gunshin et al. 1997). It has 4 isoforms (Roth 2009). DMT-1 and the TfR are up-regulated by Fe deficiency (Garcia et al. 2007). DMT-1 may work in conjunction with TfR-ME trivalent cation uptake into endosomes, in which the $\mathrm{pH}$ is dropped to $\sim 5.5$ by V-ATPase, the metal released from $\mathrm{Tf}$, and reduced to a divalent cation. DMT-1 is a $\mathrm{H}^{+}$symporter, transporting one $\mathrm{H}^{+}$and one divalent cation in the same direction (Sacher et al. 2001), with greatest activity between pH 5.5 and 6.5 (Picard et al. 2000). A DMT-1 antibody decreased Mn uptake by erythroleukemia-like K562 cells (Conrad et al. 2000).

DMT-1 was identified at the BBB in the normal and Belgrade rat (Burdo et al. 2001; Burdo et al. 2003). It was suggested to mediate direct cellular uptake of Fe at the plasma membrane as well as efflux of Fe from the endosome after its release from $\mathrm{Tf}$, as discussed in the previous paragraph (Fleming et al. 1998; Garrick et al. 1999). This is shown in Figure 2 of (Roth 2009). A subsequent study did not find DMT-1 expression in monkey BMECs, but in astrocyte foot processes (Wang et al. 2001), whereas further work by this group reported DMT-1 in developing 
rat brain BMECs (Siddappa et al. 2003; Siddappa et al. 2002). Others were unable to verify DMT1 expression in normal (post-natal day 1 to adult) or Belgrade rat BMECs or neonatal rat brain (Ke et al. 2005). A BBB Fe efflux transporter ferroportin (aka: Ireg, MTP1 and SLC11A3) has been suggested to mediate the export of divalent cations across the abluminal membrane of BMECs (Wu et al. 2004). However, another group failed to detect ferroportin in BMECs (Burdo et al. 2003).

The effect of $\mathrm{pH}$ on $\mathrm{Mn}^{2+}$ ion uptake into bovine BMECs (bBMECs) was assessed from media buffered to $\mathrm{pH} 6.4,6.9,7.4$, and 7.9. Primary bBMECs are a classical model of the BBB (Audus et al. 1996). Mn uptake positively correlated with $\mathrm{pH}$ (Crossgrove and Yokel 2005). Increased $\mathrm{Mn}^{2+}$ ion uptake in the presence of reduced $\mathrm{H}^{+}$concentration is not consistent with $\mathrm{a} \mathrm{H}^{+}-$ dependent carrier. Studies were conducted with RBE4 cells, an immortalized cell line derived from rat BMECs, grown to confluence on porous filters in the absence and presence of astrocyteconditioned medium (Fitsanakis et al. 2006; Fitsanakis et al. 2005). The filters were suspended between two fluid compartments. RBE4 cells do not form tight junctions even when co-cultured with astrocytes (Françoise Roux, personal communication, May 2000), so may not be a good model for studies of transendothelial transport. The integrity of the tight junctions was not reported for these studies, although it was demonstrated that addition of astrocyte-conditioned medium significantly reduced Mn flux across the cells (Fitsanakis et al. 2005). In these cells, Mn flux inversely correlated with $\mathrm{pH}$, from 7 to 7.8 , suggesting $\mathrm{Mn}$ flux may be related to $\mathrm{H}^{+}$currents (Fitsanakis et al. 2006; Fitsanakis et al. 2005).

To test the hypothesis that DMT-1 may mediate brain Mn uptake, the $\mathrm{K}_{\text {in }}$ values of the $\mathrm{Mn}^{2+}$ ion and $\mathrm{Mn}$ Tf were determined in homozygous and heterozygous Belgrade rats, compared to Wistar rats, from which Belgrade rats were derived. The homozygous recessive Belgrade rat $(b / b)$ 
expresses a form of DMT-1 that is not functional for cation uptake, whereas their heterozygous littermates (+/b) are phenotypically normal. Mn uptake into reticulocytes, intestinal Mn absorption, olfactory nerve Mn uptake (Thompson et al. 2007) and Mn concentration in liver and kidney were lower in $b / b$ than $(+/ b)$ or Wistar rats. Endogenous brain Mn was lower (5 and $25 \%$ ), but not significantly, in adult $b / b$ than $(+/ b)$ or Wistar rats $2 \mathrm{hr}$ after iv injection of $\mathrm{Mn}$ as $\mathrm{Mn} \mathrm{Tf}$ or in serum. Brain Mn was lower in 15-day old rats after Mn injection and adult rats after both Mn species (Chua and Morgan 1997).

Using the in situ brain perfusion technique, uptake of the $\mathrm{Mn}^{2+}$ ion and $\mathrm{Mn} \mathrm{Tf}$ were determined into the nine brain regions noted above of $b / b$, littermate $+/ b$, and control rats. No statistically significant differences in $\mathrm{K}_{\text {in }}$ values were seen. Nor were there significant differences in the percentage of $\mathrm{Mn}$ in the isolated brain capillaries among the $b / b,+/ b$ and Wistar rats following $\mathrm{Mn}^{2+}$ ion or Mn Tf perfusion (Crossgrove and Yokel 2004). This is consistent with the lack of difference in the amount of Fe in BMECs among $b / b,+/ b$ and Wistar rats (Burdo et al. 1999). These results suggest DMT-1 does not have an essential role in brain Mn uptake. The Health Effects Institute Health Review Committee opined that "In experiments to identify the transporters for Mn influx, the investigators convincing ruled out the involvement of the metal transporter DMT1..." (Yokel and Crossgrove 2004), p. 67. However, it has been suggested that these studies were not sufficient to exclude a role for DMT-1 in Mn transport at the BBB; that the rate-limiting step may be the transfer of Mn out of the cell, for which the optimal pH may be near 7 (Roth 2006) and that the potential for adaptation and compensation due to DMT-1 deficiency may be relevant (Au et al. 2008). Another possibility might be that DMT-1 expression is sufficient (albeit very low) in the Belgrade rat to mediate Mn transport. There is considerable debate about the role of DMT-1 in Mn distribution, particularly across the BBB. Further work to definitively determine the location 
of DMT-1 expression at the BBB would help to clarify the controversy whether or not it plays a role in brain Mn uptake. Other approaches will also be necessary to resolve this controversy.

Missense mutations of DMT-1, such as that of the Belgrade rat and $\mathrm{mk} / \mathrm{mk}$ mouse are evidently not expressed in the human. However, a missense mutation of the HFE gene is seen in $90 \%$ of hereditary hemochromatosis patients. The HFE protein complexes with transferrin receptors, lowering Fe uptake (Griffiths et al. 2000). Therefore, enhanced TfR-ME Mn uptake might occur in this population. The finding that dihydropyridine L-type voltage sensitive calcium channel blockers prolong Fe transport by DMT-1 suggests a possible interaction between these systems for Mn uptake (Ludwiczek et al. 2007).

To determine if $\mathrm{Mn}^{2+}$ ion uptake was mediated by a Na-dependent process, its uptake into bBMECs from media in which 50 or $100 \%$ of the $\mathrm{Na}$ was replaced with choline or lithium was determined. Mn uptake was not inhibited by Na replacement. In contrast, Mn uptake was significantly increased from a choline-containing media (Crossgrove and Yokel 2005). Similarly, replacement of $\mathrm{Na}$ by choline had no significant effect on Mn flux across RBE4 cells (Fitsanakis et al. 2006; Fitsanakis et al. 2005).

The energy dependence of $\mathrm{Mn}^{2+}$ ion uptake was assessed as its uptake into bBMECs in the presence of metabolic inhibitors, DNP, which releases $\mathrm{H}^{+}$gradients and causes $\mathrm{Ca}^{2+}$ release from mitochondria to prevent the driving force of ATP production) (Lynch and Deth 1984); azide, which inhibits complex IV in the electron transport chain (Cheng et al. 2001), and 2-deoxyglucose, which is metabolically inactive and cannot enter into the glycolysis pathway (Cheng et al. 2001). These inhibitors reduced the conversion of MTT (by a mitochondrial reductase) to its formazan product to $\sim 60 \%$ of control, but did not significantly affect $\mathrm{Mn}^{2+}$ ion uptake. These results suggest $\mathrm{Mn}^{2+}$ ion 
uptake is not directly dependent on a source of energy mediated by ATP hydrolysis (Crossgrove and Yokel 2005). However, concentrative uptake relies on an energy source or electron transfer. The $\mathrm{pH}$ dependence of $\mathrm{Mn}$ uptake suggested that it might be driven by an electromotive force, such as $\mathrm{a} \mathrm{H}^{+}$or cation anti-porter. In contrast, mitochondrial energy inhibition produced by cyanide, rotenone or oligomycin significantly reduced Mn flux across RBE4 cells, suggesting Mn uptake is an energy-dependent active process (Fitsanakis et al. 2006; Fitsanakis et al. 2005).

There are known interactions between Fe and Mn. High Fe intake reduced oral and lung Mn absorption (Davis et al. 1992). Over 7\% of Mn was orally absorbed by Fe-deficient humans vs. 3\% by normal individuals (Mena et al. 1969). Mn absorption increased in young women who consumed a low-Fe diet (Finley 1999). Fe-depletion generally increased brain Mn in rats, although it decreased hippocampal Mn. In contrast, Fe-deficiency did not increase brain Mn in post-natal day 21 rats (Garcia et al. 2007). However some studies also showed increased brain Mn in Feloaded rats (Chua and Morgan 1996; Erikson et al. 2002; Erikson et al. 2004; Fitsanakis et al. 2009; Fitsanakis et al. 2008; Kwik-Uribe et al. 2000).

To assess a Fe-Mn interaction at the BBB, rats were iv infused with $\mathrm{Fe}(\mathrm{OH})$ dextran for $6 \mathrm{~h}$ followed by carotid artery $\mathrm{MnCl}_{2}$ injection and sacrificed $15 \mathrm{~s}$ later. Brain $\mathrm{Mn}$ inversely correlated with the Fe dextran dose (Aschner and Aschner 1990). A further test of common processes that mediate brain Fe and $\mathrm{Mn}$ uptake was conducted in rats using the in situ brain perfusion technique and perfusates void of, or containing, antioxidants and $\mathrm{Fe}^{2+}$. Iron, in the absence or presence of antioxidants, did not significantly decrease brain Mn uptake. To the contrary, the non-significant trend was for Fe to increase brain Mn uptake (Yokel and Crossgrove 2004). Depletion of Fe (by inclusion of the Fe chelator desferrioxamine in the culture medium) and Fe supplementation (by incubation of monocultures in Fe dextran) increased Mn flux into RBE4 cells (Fitsanakis et al. 
2006; Fitsanakis et al. 2005). The authors suggest the increased uptake could be due to a Mndextran complex, mediated by a mechanism similar to Mn citrate uptake. These results suggest brain Mn uptake is not mediated by a carrier that transports both Fe and $\mathrm{Mn}$ into the brain, such as DMT-1, unless the transporter's $V_{\max }$ is much larger than the concentrations of $\mathrm{Fe}$ and $\mathrm{Mn}$ tested.

$\mathrm{Mn}^{2+}$ has the same charge and relative size as $\mathrm{Ca}^{2+}$, suggesting a Ca carrier might mediate brain Mn uptake. There is evidence for Mn-Ca interactions. Ca inhibitors, reduced temperature, and divalent cations, including $\mathrm{Ni}$, reduced $\mathrm{Mn}$ uptake into human hepatocarcinoma (Hep-G2) cells (Finley 1998). Mn has been extensively used as a surrogate for $\mathrm{Ca}$ in uptake studies because it enters cells by the same pathway as Ca influx (Ambudkar et al. 1992). Ca cycles include the release of endoplasmic $\mathrm{Ca}$ stores into cytosol during $\mathrm{Ca}$ oscillations which are produced by a variety of events. Sarco-endoplasmic reticulum $\mathrm{Ca}^{2+}$ ATPases (SERCAs) pump intracellular free Ca from the cytoplasm into the endoplasmic reticulum or out of the cell (plasma membrane Ca pump) to recover from the flood of cytosolic $\mathrm{Ca}$. When intracellular stores are Ca depleted, an unknown signal opens the plasma membrane store-operated Ca permeable channel (SOCC) to allow Ca entry from extracellular fluid. A role for a Ca uptake process mediating brain Mn uptake was supported by the finding that the Ca concentration in the uptake medium of in situ brain perfusion experiments negatively correlated with $\mathrm{Mn}^{2+}$ ion influx into rat brain (Crossgrove and Yokel 2005).

The p-type (plasma membrane) ATPases are channels linked with ATP hydrolysis that pump protons across the cell membrane, including $\mathrm{Na} / \mathrm{K}-\mathrm{ATPase}$ and $\mathrm{Ca}-\mathrm{ATPase}$. Ouabain, a selective $\mathrm{Na} / \mathrm{K}-\mathrm{ATPase}$ inhibitor, did not inhibit $\mathrm{Mn}^{2+}$ ion uptake into bBMECs (Crossgrove and Yokel 2005). Ca-ATPase is a plasma membrane Ca pump located on BCECs (Carafoli and Brini 2000). 
$\mathrm{Ca}^{2+} / \mathrm{Mn}^{2+}$-p-type-ATPases (SPCA2) are quite Mn-specific secretory pathways; however, their expression in BMECs has apparently not been investigated (Xiang et al. 2005). Vanadate, a non-specific inhibitor of p-type ATPases, including Ca-ATPase (Tiffert and Lew 2001), inhibited Mn uptake into bBMECs (Crossgrove and Yokel 2005).

The hypothesis that brain $\mathrm{Mn}^{2+}$ ion uptake is mediated by a $\mathrm{Ca}^{2+}$-ATPase was further tested using the in situ brain perfusion technique. Vanadate or $p$-hydroxyhippuric acid, a specific inhibitor of $\mathrm{Ca}^{2+}-$ ATPase (Jankowski et al. 2001), was included in the perfusate. In this experimental procedure, vanadate increased, rather than decreased, $\mathrm{Mn} \mathrm{K}_{\text {in }}$ (Crossgrove and Yokel 2005). $p$ Hydroxyhippuric acid did not significantly decrease brain Mn uptake (Crossgrove and Yokel 2005). These results fail to support a role for a $\mathrm{Ca}^{2+}$ ATPase in brain Mn uptake.

The gating of SOCCs is controlled by sarcoplasmic reticulum Ca pump function. It has not been specifically identified but is thought to be homologous to the transient receptor potential (TRP) gene family, e.g., TRP7 (Riccio et al. 2002). The Mn ion enters rat peritoneal mast cells, osteoblast-like cells and human platelets through SOCC (Baldi et al. 2002; Dobrydneva and Blackmore 2001; Fasolato et al. 1993a; Fasolato et al. 1993b) and human umbilical vein endothelial cells via a mechanism blocked by $\mathrm{Ni}$ and inversely related to extent of fullness of an internal Ca store (Jacob 1990). Based on the use of several of the below pharmacological probes, Mn uptake from the lung was attributed to L-type Ca channels and a member of the TRP family (Heilig et al. 2006). Evidence of SOCCs in brain endothelial cells has been reported (Kerper and Hinkle 1997b; Kim et al. 2004), which mediate lead uptake (Kerper and Hinkle 1997b).

To determine if brain Mn uptake occurs via a SOCC, the $\mathrm{K}_{\text {in }}$ of the $\mathrm{Mn}^{2+}$ ion was determined from perfusates containing nifedipine and verapamil, inhibitors of L-type voltage-gated Ca channels, 
which are expressed by BMECs (Bossu et al. 1992); $\mathrm{La}\left(\mathrm{NO}_{3}\right)_{3}$, an inhibitor of a variety of Ca channels; or $\mathrm{NiCl}_{2}$, which inhibits $\mathrm{Ca}$ flux through plasma membrane channels. None of these agents significantly decreased Mn brain uptake (Crossgrove and Yokel 2005). However $\mathrm{Ni}^{2+}$ profoundly reduced Mn uptake into bBMECs, suggesting a role for Ca channels in Mn uptake (Crossgrove and Yokel 2005). Ni has been shown to inhibit receptor-operated Ca channels and SOCC (Cui and Dannies 1992; Kukkonen et al. 2001). Ni is thought to be a rather specific Ca channel inhibitor, as it did not appear to be a substrate for the channels it blocks (Jones and Sharpe 1994; Shibuya and Douglas 1992). Pre-treatment with agents that inhibit SERCA ATPase to cause release and depletion of intracellular Ca stores (cyclopiazonic acid and thapsigargin; (Kerper and Hinkle 1997b)) significantly increased Mn uptake into bBMECs (Crossgrove and Yokel 2005). Thapsigargin was shown to increase Mn entry into rat parotid acinar cells (Ambudkar et al. 1992), thymic lymphocytes (Mason et al. 1993) and a non-excitable clone of human embryonic kidney cells (HEK293) (Kerper and Hinkle 1997a). These results suggest a possible role of SOCCs in Mn uptake. The $\mathrm{pH}$ dependence of brain Mn uptake is also consistent with a role for SOCC in brain Mn influx, as store-operated Ca influx into microglia was inhibited by low extracellular $\mathrm{pH}$ (Khoo et al. 2001). These results are consistent with the proposed uptake of Mn from the gastrointestinal tract by processes that mediate Ca uptake (Leblondel and Allain 1999).

A putative carrier for $\mathrm{Mn}$ citrate was suggested to be the monocarboxylate transporter (MCT), a $\mathrm{H}^{+}$ co-transporter. At dilute $\mathrm{Mn}$ and citrate concentrations and $\mathrm{pH} \sim 7.35$ the central carboxylate of the 1:1 Mn:citrate complex is non-coordinated and negatively charged, therefore an organic anion (Amico and Daniele 1979). These are the conditions of brain extracellular fluid, blood plasma, and the in situ brain perfusate. Other suggested candidates for Mn citrate transport are members of the organic anion transporter polypeptide (Oatp) or ATP-binding cassette (ABC) superfamilies. 
Mn citrate uptake was assessed in b.End5 cells that were shown to express MCT-1 (Yokel et al. 2002). Uptake was greater from $\mathrm{pH} 6.9$ than $\mathrm{pH} 7.4$ media, suggesting a $\mathrm{H}^{+}$-dependent uptake mechanism (Yokel and Crossgrove 2004), consistent with the possibility that MCT-1 mediates Mn citrate uptake. To determine if the $\mathrm{Mn}$ citrate carrier is a member of the family of organic anion transporters, rats were perfused, during in situ brain perfusion, with Mn citrate in the near absence of $\mathrm{Na}$ (a potential co-substrate of some transporters) and in the presence of quercetin (which inhibits several transporters, including MCT-1) (Poole and Halestrap 1993). Low Na had no significant effect (Yokel and Crossgrove 2004). Quercetin significantly, but incompletely, reduced Mn citrate brain uptake (Yokel and Crossgrove 2004). The incomplete inhibition by quercetin suggests that either the quercetin concentration was insufficient to block all the transporters or that more than one carrier is responsible for Mn citrate brain uptake.

\section{Mn brain efflux rates and mechanisms}

Efflux of $\mathrm{Mn}$ from cells and the brain has received very little attention. Work in vitro showed Mn efflux from cultured chick glial cells (Wedler et al. 1989). As noted above, Mn is actively transported out of astrocytes (Aschner et al. 1992). Glial cell Mn efflux would not result in Mn efflux out of the brain.

One of the few methods to determine the rate of brain efflux was described by (Kakee et al. 1996). In this method the rate of brain $\mathrm{Mn}$ efflux ( $\mathrm{K}_{\text {out }}$ or $\mathrm{Cl}_{\text {efflux, }}$ a brain efflux rate term comparable to $\mathrm{K}_{\text {in }}$ ) is calculated from the volume of distribution of the test substance in the brain $\left(\mathrm{V}_{\text {brain }}\right)$ and its rate of disappearance from the brain after discrete microinjection $\left(\mathrm{K}_{\mathrm{el}}\right)$. $\mathrm{K}_{\mathrm{el}}$ is determined from the brain efflux index $(\mathrm{BEI})$, the percentage of substance injected into the brain that has effluxed from brain to blood across the BBB. An "impermeable reference compound" that very slowly diffuses across the BBB during the time course of the experiments, serving the same function as $\left[{ }^{14} \mathrm{C}\right]$-sucrose in 
the in situ brain perfusion technique, is included in the brain injectate to quantify its volume. This method enables control of the chemical species of test substance introduced into the brain.

To determine the rate of brain $\mathrm{Mn}$ efflux, $\mathrm{V}_{\text {brain }}$ was determined for the $\mathrm{Mn}^{2+}$ ion, $\mathrm{Mn}$ citrate and $\mathrm{Mn}$ Tf from uptake into parietal Par2 slices in vitro. Brain slice Mn concentration increased over time to a significantly greater extent than $\left[{ }^{14} \mathrm{C}\right]$-sucrose for each $\mathrm{Mn}$ species, and was concentrative. To determine $\mathrm{BEI}$, the $\mathrm{Mn}^{2+}$ ion or $\mathrm{Mn}$ citrate and $\left[{ }^{14} \mathrm{C}\right]$-sucrose or $\left[{ }^{14} \mathrm{C}\right]$-dextran were co-injected (in $0.2 \mu \mathrm{l}$ ) into rat parietal cortex. The rats were terminated at various times. Nearly $99 \%$ of the $\mathrm{Mn}$ remaining in the brain was in the central $1 / 3$ of the hemisphere ipsilateral to the injection, indicating very little distribution from the injection site within the brain. Graphs of BEI results, as 100-BEI (\%) versus time, an indication of the percentage of Mn remaining in the brain after its injection, showed a small increase of the injected $\mathrm{Mn}$ remaining in the brain over time, compared to co-injected ${ }^{14} \mathrm{C}$-sucrose or ${ }^{14} \mathrm{C}$-dextran. As $100-\mathrm{BEl}$ increased over time after $\mathrm{Mn}^{2+}$ ion and $\mathrm{Mn}$ citrate injection, $\mathrm{K}_{\mathrm{el}}$ and $\mathrm{K}_{\text {out }}$ could not be calculated. The 100-BEI values after the injection of these $2 \mathrm{Mn}$ species into the brain were very similar, believed to be due to rapid equilibration to the same Mn species, as noted in the discussion of Mn re-speciation above. Mn species, calculated by Dr. Wesley Harris, University of Missouri-St. Louis, based on the composition and concentration of ligands in cerebrospinal fluid, suggested they would be predominantly the $\mathrm{Mn}^{2+}$ ion (56\%), Mn citrates (20\%), and Mn phosphate (15\%), consistent with the quantification of $\mathrm{Mn}$ species in human CSF (Nischwitz et al. 2008).

The slightly increasing 100-BEI Mn values over time are consistent with the slightly slower predicted diffusion rate of $\mathrm{Mn}$ than sucrose or dextran (Table 1). These results suggest brain $\mathrm{Mn}$ efflux is mediated by diffusion. A physiologically based pharmacokinetic model that described the results of 3 studies of $\mathrm{Mn}$ uptake in rats had a half-life of brain Mn influx several-fold shorter than 
the half-life of brain efflux, consistent with more rapid brain Mn influx than efflux (Nong et al. 2008).

The conclusion that brain Mn efflux may not occur via active transport was challenged in a White Paper by Taylor et al of the Ethyl Corporation suggesting an alternative explanation might be Mn uptake by astrocytes, reducing the pool of available Mn for efflux from the brain. The Health Effects Institute's Health Review Committee noted that even if that was true, the Mn would remain in the brain, and the Mn taken up by the astrocytes might contribute to the neurotoxic effects of Mn (HEI response January 3, 2005).

As a result of the observation of higher brain Mn concentration in aceruloplasminemic than wild mice and prior suggestions that brain ceruloplasmin facilitates $\mathrm{Fe}$ efflux by oxidation of $\mathrm{Fe}^{2+}$ to $\mathrm{Fe}^{3+}$, the authors speculated that ceruloplasmin may play a role in brain Mn efflux (Jursa and Smith 2009). This hypothesis could be tested.

The findings that brain $\mathrm{Mn}$ influx is more rapid than efflux is consistent with slower Mn elimination from the brain than other compartments, and brain Mn accumulation during repeated/continuous exposure. After injection, the decrease of Mn over time was slower from the brain than from most tissues (Drown et al. 1986). Little decrease of cerebral Mn was seen in the monkey up to 278 days after its peripheral injection (Dastur et al. 1971). The half-life of Mn in sixteen rat brain regions was estimated to range from 52 to 74 days (Takeda et al. 1995), compared to whole body Mn elimination half-lives of 2.4 to 3.8 and 25 to 32 days and averages of 6 and 43 days in rats (Dorman et al. 2001a; Dorman et al. 2001b). A single iv injection of Mn in 3 humans showed whole body and head biological half-lives of 15 to 37.5 and 37 to 62 days, respectively (Cotzias et al. 1968). After inhalation, the half-life of Mn elimination from the brain of 2 macaque monkeys 
was 223 to 267 days vs. 3 phases of elimination with half-lives of $<1,12$ to 27 , and 94 to 187 days from the chest area (Newland et al. 1987). Increased brain Mn concentration was seen following repeated Mn exposures (Gianutsos et al. 1985), suggesting steady-state conditions were not met.

In summary, the results from several groups show evidence of the presence of BBB carriers that mediate the influx of $\mathrm{Mn}^{2+}$ ion, Mn citrate and $\mathrm{Mn}$ Tf into the brain. Each of these carriers would increase the rate of brain Mn entry over that provided by diffusion. Evidence has been provided for $\mathrm{Mn} \mathrm{Tf}$ and $\mathrm{Mn}^{2+}$ ion uptake across the BBB mediated by TfR-ME and SOCC. The role of DMT-1 remains controversial. There is evidence against, but no direct evidence supporting, its role. The results from the only study of brain Mn efflux suggest it is diffusion mediated. In light of carrier-mediated brain influx but not efflux, it would be anticipated that the half-life of Mn in the brain may be greater than other compartments. Several reports have shown this. It would be expected that repeated, excessive Mn exposure might result in brain Mn accumulation over time, which has been shown. 


\section{Acknowledgement:}

This work was supported by Health Effects Institute Assistance Award R-824835, NIH Grant T32 ES7266 and the University of Kentucky Graduate School. The author thanks Matt Hazzard, University of Kentucky Teaching \& Academic Support Center, for preparing Fig. 1. 
Figure 1. Sites where Mn flux across mammalian membranes has been described, the direction of the flux, flux mechanism(s) when identified, and reference(s) are shown in the human.

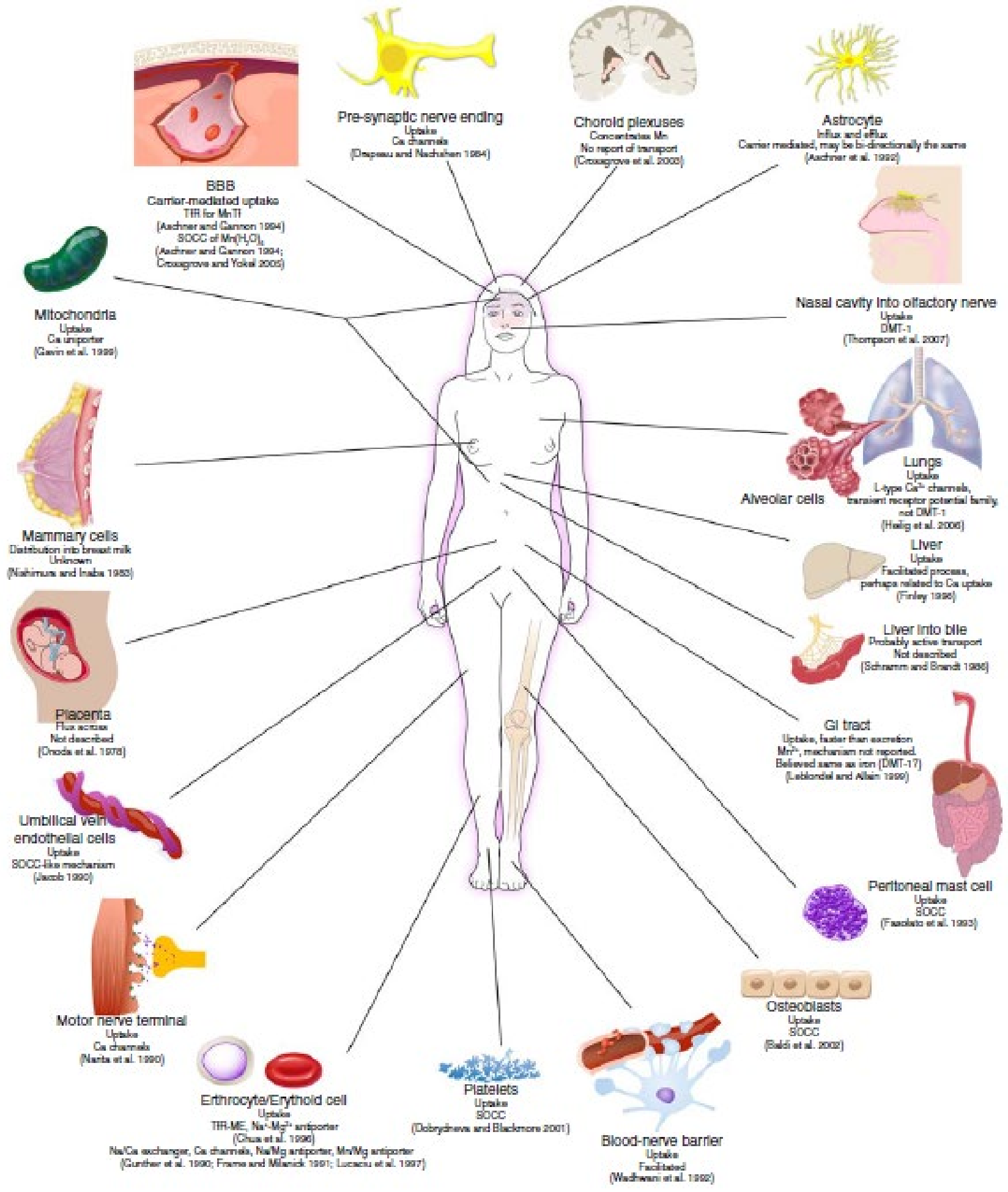




\section{References:}

Aisen P., Aasa R. and Redfield A. G. (1969). The chromium, manganese, and cobalt complexes of transferrin. J Biol Chem, 244, 4628-4633.

Ambudkar I. S., Lockwich T., Hiramatsu Y. and Baum B. J. (1992). Calcium entry in rat parotid acinar cells. Mol Cell Biochem, 114, 73-77.

Amico P. and Daniele P. G. (1979). Equilibrium study of iron (II) and manganese (I) complexes with citrate ion in aqueous solution: relevance to coordination of citrate to the active site of aconitase and to gastrointestinal absorption of some essential metal ions. Inorg Chim Acta, $36,1-7$.

Aschner M. and Aschner J. L. (1990). Manganese transport across the blood-brain barrier: relationship to iron homeostasis. Brain Res Bull, 24, 857-860.

Aschner M. and Gannon M. (1994). Manganese (Mn) transport across the rat blood-brain barrier: saturable and transferrin-dependent transport mechanisms. Brain Res Bull, 33, 345-349.

Aschner M., Gannon M. and Kimelberg H. K. (1992). Manganese uptake and efflux in cultured rat astrocytes. J Neurochem, 58, 730-735.

Au C., Benedetto A. and Aschner M. (2008). Manganese transport in eukaryotes: the role of DMT1. NeuroToxicology, 29, 569-576.

Audus K. L., Ng L., Wang W. and Borchardt R. T. (1996). Brain microvessel endothelial cell culture systems. Pharmaceut Biotechnol, 8, 239-258.

Baldi C., Vazquez G. and Boland R. (2002). Characterization of a 1,25(OH)2-vitamin D3responsive capacitative $\mathrm{Ca}^{2+}$ entry pathway in rat osteoblast-like cells. J Cell Biochem, 86, 678-687. 
Bossu J. L., Elhamdani A., Feltz A., Tanzi F., Aunis D. and Thierse D. (1992). Voltage-gated Ca entry in isolated bovine capillary endothelial cells: evidence of a new type of BAY K 8644sensitive channel. Pflugers Arch, 420, 200-207.

Bradbury M. W. (1997). Transport of iron in the blood-brain-cerebrospinal fluid system. J Neurochem, 69, 443-454.

Burdo J. R., Martin J., Menzies S. L., Dolan K. G., Romano M. A., Fletcher R. J., Garrick M. D., Garrick L. M. and Connor J. R. (1999). Cellular distribution of iron in the brain of the Belgrade rat. Neuroscience, 93, 1189-1196.

Burdo J. R., Menzies S. L., Simpson I. A., Garrick L. M., Garrick M. D., Dolan K. G., Haile D. J., Beard J. L. and Connor J. R. (2001). Distribution of divalent metal transporter 1 and metal transport protein 1 in the normal and Belgrade rat. J Neurosci Res, 66, 1198-1207.

Burdo J. R., Simpson I. A., Menzies S., Beard J. and Connor J. R. (2003). Regulation of the profile of iron - management proteins in brain microvasculature. J Cereb Blood Flow Metab 24, 6774.

Burgess J. (1992). Kinetic aspects of chemical speciation. Analyst, 117, 605-611.

Carafoli E. and Brini M. (2000). Calcium pumps: structural basis for and mechanism of calcium transmembrane transport. Curr Opin Chem Biol, 4, 152-161.

Chandra S. V., Shukla G. S., Srivastava R. S., Singh H. and Gupta V. P. (1981). An exploratory study of manganese exposure to welders. Clin Toxicol, 18, 407-416.

Cheng A. M., Morrison S. W., Yang D. X. and Hagen S. J. (2001). Energy dependence of restitution in the gastric mucosa. Am J Physiol Cell Physiol, 281, C430-C438.

Chong W. S., Kwan P. C., Chan L. Y., Chiu P. Y., Cheung T. K. and Lau T. K. (2005). Expression of divalent metal transporter 1 (DMT1) isoforms in first trimester human placenta and embryonic tissues. Hum Reprod, 20, 3532-3538. 
Chua A. C. and Morgan E. H. (1996). Effects of iron deficiency and iron overload on manganese uptake and deposition in the brain and other organs of the rat. Biol Trace Elem Res, 55, 3954.

Chua A. C. and Morgan E. H. (1997). Manganese metabolism is impaired in the Belgrade laboratory rat. J Comp Physiol. B, Biochem, Systemic, Environ Physiol, 167, 361-369.

Chua A. C., Stonell L. M., Savigni D. L. and Morgan E. H. (1996). Mechanisms of manganese transport in rabbit erythroid cells. J Physiol, 493 ( Pt 1), 99-112.

Cole E. S. and Glass J. (1983). Transferrin binding and iron uptake in mouse hepatocytes. Biochim Biophys Acta, 762, 102-110.

Conrad M. E., Umbreit J. N., Moore E. G., Hainsworth L. N., Porubcin M., Simovich M. J., Nakada M. T., Dolan K. and Garrick M. D. (2000). Separate pathways for cellular uptake of ferric and ferrous iron. Am J Physiol Gastrointest Liver Physiol, 279, G767-G774.

Cotzias G. C., Horiuchi K., Fuenzalida S. and Mena I. (1968). Chronic manganese poisoning. Clearance of tissue manganese concentrations with persistance of the neurological picture. Neurology, 18, 376-382.

Crossgrove J. S., Allen D. D., Bukaveckas B. L., Rhineheimer S. S. and Yokel R. A. (2003). Manganese distribution across the blood-brain barrier. I. Evidence for carrier-mediated influx of managanese citrate as well as manganese and manganese transferrin. NeuroToxicology, 24, 3-13.

Crossgrove J. S. and Yokel R. A. (2004). Manganese distribution across the blood-brain barrier III. The divalent metal transporter-1 is not the major mechanism mediating brain manganese uptake. NeuroToxicology, 25, 451-460.

Crossgrove J. S. and Yokel R. A. (2005). Manganese distribution across the blood-brain barrier. IV. Evidence for brain influx through store-operated calcium channels. NeuroToxicology, 26, 297-307. 
Cui Z. J. and Dannies P. S. (1992). Thyrotropin-releasing hormone-mediated $\mathrm{Mn}^{2+}$ entry in perifused rat anterior pituitary cells. Biochem J, 283 ( Pt 2), 507-513.

Dastur D. K., Manghani D. K. and Raghavendran K. V. (1971). Distribution and fate of ${ }^{54} \mathrm{Mn}$ in the monkey: studies of different parts of the central nervous system and other organs. J Clin Invest, 50, 9-20.

Davidsson L., Lonnerdal B., Sandstrom B., Kunz C. and Keen C. L. (1989). Identification of transferrin as the major plasma carrier protein for manganese introduced orally or intravenously or after in vitro addition in the rat. J Nutr, 119, 1461-1464.

Davis C. D., Wolf T. L. and Greger J. L. (1992). Varying levels of manganese and iron affect absorption and gut endogenous losses of manganese by rats. J Nutr, 122, 1300-1308.

Dickinson T. K., Devenyi A. G. and Connor J. R. (1996). Distribution of injected iron 59 and manganese 54 in hypotransferrinemic mice. J Lab Clin Med, 128, 270-278.

Dobrydneva Y. and Blackmore P. (2001). 2-Aminoethoxydiphenyl borate directly inhibits storeoperated calcium entry channels in human platelets. Mol Pharmacol, 60, 541-552.

Dorman D. C., Struve M. F., James R. A., Marshall M. W., Parkinson C. U. and Wong B. A. (2001a). Influence of particle solubility on the delivery of inhaled manganese to the rat brain: manganese sulfate and manganese tetroxide pharmacokinetics following repeated (14-day) exposure. Toxicol Appl Pharmacol, 170, 79-87.

Dorman D. C., Struve M. F., James R. A., McManus B. E., Marshall M. W. and Wong B. A. (2001b). Influence of dietary manganese on the pharmacokinetics of inhaled manganese sulfate in male CD rats. Toxicol Sci, $60,242-251$.

Drapeau P. and Nachshen D. A. (1984). Manganese fluxes and manganese-dependent neurotransmitter release in presynaptic nerve endings isolated from rat brain. J Physiol, 348, 493-510. 
Drown D. B., Oberg S. G. and Sharma R. P. (1986). Pulmonary clearance of soluble and insoluble forms of manganese. J Toxicol Environ Health, 17, 201-212.

Edlund G. L. and Halestrap A. P. (1988). The kinetics of transport of lactate and pyruvate into rat hepatocytes. Evidence for the presence of a specific carrier similar to that in erythrocytes. Biochem J, 249, 117-126.

Erikson K. M., Shihabi Z. K., Aschner J. L. and Aschner M. (2002). Manganese accumulates in iron-deficient rat brain regions in a heterogeneous fashion and is associated with neurochemical alterations. Biol Trace Elem Res, 87, 143-56.

Erikson K. M., Syversen T., Steinnes E. and Aschner M. (2004). Globus pallidus: a target brain region for divalent metal accumulation associated with dietary iron deficiency. J Nutr Biochem, $15,335-341$.

Fasolato C., Hoth M., Matthews G. and Penner R. (1993a). $\mathrm{Ca}^{2+}$ and $\mathrm{Mn}^{2+}$ influx through receptormediated activation of nonspecific cation channels in mast cells. Proc Natl Acad Sci U S A, 90, 3068-3072.

Fasolato C., Hoth M. and Penner R. (1993b). Multiple mechanisms of manganese-induced quenching of fura-2 fluorescence in rat mast cells. Pflugers Arch, 423, 225-231.

Ferraz H. B., Bertolucci P. H., Pereira J. S., Lima J. G. and Andrade L. A. (1988). Chronic exposure to the fungicide maneb may produce symptoms and signs of CNS manganese intoxication. Neurology, 38, 550-553.

Finley J. W. (1998). Manganese uptake and release by cultured human hepato-carcinoma (HepG2) cells. Biol Trace Elem Res, 64, 101-118.

Finley J. W. (1999). Manganese absorption and retention by young women is associated with serum ferritin concentration. Am J Clin Nutr, 70, 37-43. 
Fitsanakis V. A., Piccola G., Aschner J. L. and Aschner M. (2005). Manganese transport by rat brain endothelial (RBE4) cell-based transwell model in the presence of astrocyte conditioned media. J Neurosci Res, 81, 235-243.

Fitsanakis V. A., Piccola G., Aschner J. L. and Aschner M. (2006). Characteristics of manganese $(\mathrm{Mn})$ transport in rat brain endothelial (RBE4) cells, an in vitro model of the blood-brain barrier. NeuroToxicology, 27, 60-70.

Fitsanakis V. A., Thompson K. N., Deery S. E., Milatovic D., Shihabi Z. K., Erikson K. M., Brown R. W. and Aschner M. (2009). A chronic iron-deficient/high-manganese diet in rodents results in increased brain oxidative stress and behavioral deficits in the morris water maze. Neurotox Res, 15, 167-178.

Fitsanakis V. A., Zhang N., Anderson J. G., Erikson K. M., Avison M. J., Gore J. C. and Aschner M. (2008). Measuring brain manganese and iron accumulation in rats following 14 weeks of low-dose manganese treatment using atomic absorption spectroscopy and magnetic resonance imaging. Toxicol Sci, 103, 116-124.

Fleming M. D., Romano M. A., Su M. A., Garrick L. M., Garrick M. D. and Andrews N. C. (1998). Nramp2 is mutated in the anemic Belgrade (b) rat: evidence of a role for Nramp2 in endosomal iron transport. Proc NAS USA, 95, 1148-1153.

Frame M. D. and Milanick M. A. (1991). Mn and Cd transport by the Na-Ca exchanger of ferret red blood cells. Am J Physiol, 261, C467-C475.

Garcia S. J., Gellein K., Syversen T. and Aschner M. (2007). Iron deficient and manganese supplemented diets alter metals and transporters in the developing rat brain. Toxicol Sci, 95, 205-214.

Garrick L. M., Dolan K. G., Romano M. A. and Garrick M. D. (1999). Non-transferrin-bound iron uptake in Belgrade and normal rat erythroid cells. J Cell Physiol, 178, 349-358. 
Gavin C. E., Gunter K. K. and Gunter T. E. (1999). Manganese and calcium transport in mitochondria: implications for manganese toxicity. NeuroToxicology, 20, 445-453.

Georgieff M. K., Wobken J. K., Welle J., Burdo J. R. and Connor J. R. (2000). Identification and localization of divalent metal transporter-1 (DMT-1) in term human placenta. Placenta, 21, 799-804.

Gianutsos G., Seltzer M. D., Saymeh R., Wu M. L. and Michel R. G. (1985). Brain manganese accumulation following systemic administration of different forms. Arch Toxicol, 57, 272-275.

Griffiths W. J., Kelly A. L., Smith S. J. and Cox T. M. (2000). Localization of iron transport and regulatory proteins in human cells. QJM, 93, 575-587.

Gunshin H., Mackenzie B., Berger U. V., Gunshin Y., Romero M. F., Boron W. F., Nussberger S., Gollan J. L. and Hediger M. A. (1997). Cloning and characterization of a mammalian protoncoupled metal-ion transporter. Nature, 388, 482-488.

Gunter T. E., Gavin C. E., Aschner M. and Gunter K. K. (2006). Speciation of manganese in cells and mitochondria: a search for the proximal cause of manganese neurotoxicity. NeuroToxicology, 27, 765-776.

Gunther T., Vormann J. and Cragoe E. J., Jr. (1990). Species-specific $\mathrm{Mn}^{2+} / \mathrm{Mg}^{2+}$ antiport from Mg2(+)-loaded erythrocytes. FEBS Lett, 261, 47-51.

Harris W. R. and Chen Y. (1994). Electron paramagnetic resonance and difference ultraviolet studies of $\mathrm{Mn}^{2+}$ binding to serum transferrin. Journal of Inorganic Biochemistry, 54, 1-19.

Heilig E. A., Thompson K. J., Molina R. M., Ivanov A. R., Brain J. D. and Wessling-Resnick M. (2006). Manganese and iron transport across pulmonary epithelium. Am J Physiol Lung Cell Mol Physiol, 290, L1247-L1259.

Huang C. C., Chu N. S., Lu C. S., Wang J. D., Tsai J. L., Tzeng J. L., Wolters E. C. and Calne D. B. (1989). Chronic manganese intoxication. Arch Neurol, 46, 1104-1106. 
Hudnell H. K. (1999). Effects from environmental Mn exposures: a review of the evidence from non-occupational exposure studies. NeuroToxicology, 20, 379-397.

Jacob R. (1990). Agonist-stimulated divalent cation entry into single cultured human umbilical vein endothelial cells. J Physiol, 421, 55-77.

Jankowski J., Tepel M., Stephan N., van der Giet M., Breden V., Zidek W. and Schluter H. (2001). Characterization of p-hydroxy-hippuric acid as an inhibitor of $\mathrm{Ca}^{2+}$-ATPase in end-stage renal failure. Kid Int Suppl, 78, S84-S88.

Jefferies W. A., Brandon M. R., Hunt S. V., Williams A. F., Gatter K. C. and Mason D. Y. (1984). Transferrin receptor on endothelium of brain capillaries. Nature, 312, 162-163.

Jones K. T. and Sharpe G. R. (1994). $\mathrm{Ni}^{2+}$ blocks the $\mathrm{Ca}^{2+}$ influx in human keratinocytes following a rise in extracellular $\mathrm{Ca}^{2+}$. Exp Cell Res, 212, 409-413.

Jursa T. and Smith D. R. (2009). Ceruloplasmin alters the tissue disposition and neurotoxicity of manganese, but not its loading onto transferrin. Toxicol Sci, 107, 182-193..

Kakee A., Terasaki T. and Sugiyama Y. (1996). Brain efflux index as a novel method of analyzing efflux transport at the blood-brain barrier. J Pharmacol Exp Ther, 277, 1550-1559.

Kawamura R., Ikuta H., Hukuzumi S., Yamada R., Tubaki S., Kodama T. and Kurata S. (1941). Intoxication by manganese in well water. Kitasato Arch Exp Med, 18, 145-169.

Ke Y., Chang Y. Z., Duan X. L., Du J. R., Zhu L., Wang K., Yang X. D., Ho K. P. and Qian Z. M. (2005). Age-dependent and iron-independent expression of two mRNA isoforms of divalent metal transporter 1 in rat brain. Neurobiol Aging, 26, 739-748.

Kerper L. E. and Hinkle P. M. (1997a). Cellular uptake of lead is activated by depletion of intracellular calcium stores. J Biol Chem, 272, 8346-8352.

Kerper L. E. and Hinkle P. M. (1997b). Lead uptake in brain capillary endothelial cells: activation by calcium store depletion. Toxicol Appl Pharmacol, 146, 127-133. 
Ketchum K. A. (1999). Genome based comparisons of transporters, Second AAPS Frontier Symposium: Membrane transporters and drug therapy, April 8-10, 1999, NIH, Bethesda, MD. Khoo C., Helm J., Choi H. B., Kim S. U. and McLarnon J. G. (2001). Inhibition of store-operated $\mathrm{Ca}^{2+}$ influx by acidic extracellular pH in cultured human microglia. Glia, 36, 22-30.

Kim Y. V., Di Cello F., Hillaire C. S. and Kim K. S. (2004). Differential $\mathrm{Ca}^{2+}$ signaling by thrombin and protease-activated receptor-1-activating peptide in human brain microvascular endothelial cells. Am J Physiol Cell Physiol, 286, C31-C42.

Kukkonen J. P., Lund P. E. and Åkerman K. E. (2001). 2-aminoethoxydiphenyl borate reveals heterogeneity in receptor-activated $\mathrm{Ca}^{2+}$ discharge and store-operated $\mathrm{Ca}^{2+}$ influx. Cell Calcium, 30, 117-129.

Kwik-Uribe C. L., Golub M. S. and Keen C. L. (2000). Chronic marginal iron intakes during early development in mice alter brain iron concentrations and behavior despite postnatal iron supplementation. J Nutr, 130, 2040-2048.

Leblondel G. and Allain P. (1999). Manganese transport by Caco-2 cells. Biol Tr Elem Res, 67, 13-28.

Leong W. I. and Lonnerdal B. (2005). Iron transporters in rat mammary gland: effects of different stages of lactation and maternal iron status. Am J Clin Nutr, 81, 445-453.

Levin V. A. (1980). Relationship of octanol/water partition coefficient and molecular weight to rat brain capillary permeability. J Med Chem, 23, 682-684.

Liu X. and Ambudkar I. S. (2001). Characteristics of a store-operated calcium-permeable channel: sarcoendoplasmic reticulum calcium pump function controls channel gating. J Biol Chem, 276, 29891-29898.

Lucaciu C. M., Dragu C., Copaescu L. and Morariu V. V. (1997). Manganese transport through human erythrocyte membranes. An EPR study. Biochim Biophys Acta, 1328, 90-98. 
Ludwiczek S., Theurl I., Muckenthaler M. U., Jakab M., Mair S. M., Theurl M., Kiss J., Paulmichl M., Hentze M. W., Ritter M. and Weiss G. (2007). Ca ${ }^{2+}$ channel blockers reverse iron overload by a new mechanism via divalent metal transporter-1. Nat Med, 13, 448-454.

10.1038/nm1542.

Lynch C. J. and Deth R. C. (1984). Release of a common source of intracellular $\mathrm{Ca}^{2+}$ by alphaadrenergic agonists and dinitrophenol in rat liver slices. Pharmacol, 28, 74-85.

Malecki E. A., Cook B. M., Devenyi A. G., Beard J. L. and Connor J. R. (1999). Transferrin is required for normal distribution of ${ }^{59} \mathrm{Fe}$ and ${ }^{54} \mathrm{Mn}$ in mouse brain. J Neurol Sci, 170, 112-118.

Markesbery W. R., Ehmann W. D., Hossain T. I. and Alauddin M. (1984). Brain manganese concentrations in human aging and Alzheimer's disease. NeuroToxicology, 5, 49-57.

Mason M. J., Mayer B. and Hymel L. J. (1993). Inhibition of $\mathrm{Ca}^{2+}$ transport pathways in thymic lymphocytes by econazole, miconazole, and SKF 96365. Am J Physiol, 264, C654-C662.

Mena I., Horiuchi K., Burke K. and Cotzias G. C. (1969). Chronic manganese poisoning. Individual susceptibility and absorption of iron. Neurology, 19, 1000-1006.

Michalke B., Halbach S., Berthele A., Mistritiotis P. and Ochsenkuehn-Petropoulou M. (2007). Size characterization of manganese species from human serum and cerebrospinal fluid using size exclusion chromatography coupled to inductively coupled plasma mass spectrometry. $\mathrm{J}$ Anal Atomic Spect, 22, 267-272.

Miller R. K., Mattison D. R., Panigel M., Ceckler T., Bryant R. and Thomford P. (1987). Kinetic assessment of manganese using magnetic resonance imaging in the dually perfused human placenta in vitro. Environ Health Perspect, 74, 81-91.

Moore J. and Pearson R. (1981). Kinetics and Mechanism, Eds.), 3rd ed., pp. 304. Wiley, New York.

Murphy V. A., Wadhwani K. C., Smith Q. R. and Rapoport S. I. (1991). Saturable transport of manganese(II) across the rat blood-brain barrier. J Neurochem, 57, 948-954. 
Nagatomo S., Umehara F., Hanada K., Nobuhara Y., Takenaga S., Arimura K. and Osame M. (1999). Manganese intoxication during total parenteral nutrition: report of two cases and review of the literature. J Neurol Sci, 162, 102-105.

Narita K., Kawasaki F. and Kita H. (1990). Mn and Mg influxes through Ca channels of motor nerve terminals are prevented by verapamil in frogs. Brain Res, 510, 289-295.

Newland M. C., Cox C., Hamada R., Oberdorster G. and Weiss B. (1987). The clearance of manganese chloride in the primate. Fundam Appl Toxicol, 9, 314-28.

Nischwitz V., Berthele A. and Michalke B. (2008). Speciation analysis of selected metals and determination of their total contents in paired serum and cerebrospinal fluid samples: An approach to investigate the permeability of the human blood-cerebrospinal fluid-barrier. Anal Chim Acta, 627, 258-269.

Nishimura Y. and Inaba J. (1983). [Manganese metabolism in rats of various ages]. Nippon Eiseigaku Zasshi, 38, 764-771.

Nong A., Teeguarden J. G., Clewell H. J., Dorman D. C. and Andersen M. E. (2008). Pharmacokinetic modeling of manganese in the rat IV: Assessing factors that contribute to brain accumulation during inhalation exposure. J Toxicol Environ Health A, 71, 413-426.

Ono K., Komai K. and Yamada M. (2002). Myoclonic involuntary movement associated with chronic manganese poisoning. J Neurol Sci, 199, 93-96.

Onoda K., Hasegawa A., Sunouchi M., Tanaka S., Takanaka A., Omori Y. and Urakubo G. (1978). Studies on the fate of poisonous metals in experimental animals. (VII). Distribution and transplacental passage of manganese in pregnant rats and fetus Shokuhin Eiseigaku Zasshi, 19, 208-215.

Pardridge W. (2003). Blood-brain barrier drug targeting: The future of brain drug development. Mol Interventions, 3, 90-105.

Petti L. and Powell K. (1997). IUPAC stability constant database. Academic Software, Yorks, UK. 
Picard V., Govoni G., Jabado N. and Gros P. (2000). Nramp 2 (DCT1/DMT1) expressed at the plasma membrane transports iron and other divalent cations into a calcein-accessible cytoplasmic pool. J Biol Chem, 275, 35738-35745.

Poole R. C. and Halestrap A. P. (1993). Transport of lactate and other monocarboxylates across mammalian plasma membranes. Am J Physiol, 264, C761-C782.

Rabin O., Hegedus L., Bourre J. M. and Smith Q. R. (1993). Rapid brain uptake of manganese (II) across the blood-brain barrier. J Neurochem, 61, 509-517.

Reaney S. H., Kwik-Uribe C. L. and Smith D. R. (2002). Manganese oxidation state and its implications for toxicity. Chem Res Toxicol, 15, 1119-1126.

Riccio A., Mattei C., Kelsell R. E., Medhurst A. D., Calver A. R., Randall A. D., Davis J. B., Benham C. D. and Pangalos M. N. (2002). Cloning and functional expression of human short TRP7, a candidate protein for store-operated Ca ${ }^{2+}$ influx. J Biol Chem, 277, 12302-12309.

Roels H., Lauwerys R., Buchet J. P., Genet P., Sarhan M. J., Hanotiau I., de Fays M., Bernard A. and Stanescu D. (1987). Epidemiological survey among workers exposed to manganese: effects on lung, central nervous system, and some biological indices. Am J Ind Med, 11, 307327.

Roels H., Meiers G., Delos M., Ortega I., Lauwerys R., Buchet J. P. and Lison D. (1997). Influence of the route of administration and the chemical form $\left(\mathrm{MnCl}_{2}, \mathrm{MnO}_{2}\right)$ on the absorption and cerebral distribution of manganese in rats. Arch Toxicol, 71, 223-230.

Roels H. A., Ghyselen P., Buchet J. P., Ceulemans E. and Lauwerys R. R. (1992). Assessment of the permissible exposure level to manganese in workers exposed to manganese dioxide dust. Br J Ind Med, 49, 25-34.

Rossipal E. (2000). Investigation on the transport of trace elements across barriers in humans: studies of placental and mammary transfer. J Trace Microprobe Tech., 18, 493-497. 
Roth J. A. (2006). Homeostatic and toxic mechanisms regulating manganese uptake, retention, and elimination. Biol Res, 39, 45-57.

Roth J. A. (2009). Are there common biochemical and molecular mechanisms controlling manganism and parkinsonism. Neuromol Med.

Sacher A., Cohen A. and Nelson N. (2001). Properties of the mammalian and yeast metal-ion transporters DCT1 and Smf1p expressed in Xenopus laevis oocytes. J Exp Biol, 204, 10531061.

Scheuhammer A. M. and Cherian M. G. (1985). Binding of manganese in human and rat plasma. Biochim Biophys Acta, 840, 163-169.

Schramm V. L. and Brandt M. (1986). The manganese(II) economy of rat hepatocytes. Fed Proc, 45, 2817-2820.

Shibuya I. and Douglas W. W. (1992). Calcium channels in rat melanotrophs are permeable to manganese, cobalt, cadmium, and lanthanum, but not to nickel: evidence provided by fluorescence changes in fura-2-loaded cells. Endocrinol, 131, 1936-1941.

Siddappa A. J., Rao R. B., Wobken J. D., Casperson K., Leibold E. A., Connor J. R. and Georgieff M. K. (2003). Iron deficiency alters iron regulatory protein and iron transport protein expression in the perinatal rat brain. Pediatr Res, 53, 800-807.

Siddappa A. J., Rao R. B., Wobken J. D., Leibold E. A., Connor J. R. and Georgieff M. K. (2002). Developmental changes in the expression of iron regulatory proteins and iron transport proteins in the perinatal rat brain. J Neurosci Res, 68, 761-75.

Sjögren B., Gustavsson P. and Hogstedt C. (1990). Neuropsychiatric symptoms among welders exposed to neurotoxic metals. $\mathrm{Br} \mathrm{J}$ Ind Med, 47, 704-707.

Sjögren B., Iregren A., Frech W., Hagman M., Johansson L., Tesarz M. and Wennberg A. (1996).

Effects on the nervous system among welders exposed to aluminium and manganese. Occupat Environ Med, 53, 32-40. 
Smith Q. R. (1989). Quantitation of blood-brain barrier permeability. (E. A. Neuwelt, Eds.), pp. 85118. Plenum Publishing Corporation, New York.

Sugawara N., Li D. and Sugawara C. (1994). Biliary excretion of exogenous cadmium and manganese in Long-Evans Cinnamon (LEC) rats characterized by an inherently gross amount of copper-metallothionein in the liver. Arch Toxicol, 68, 520-523.

Takasato Y., Rapoport S. I. and Smith Q. R. (1984). An in situ brain perfusion technique to study cerebrovascular transport in the rat. Am J Physiol, 247, H484-H493.

Takeda A. (2003). Manganese action in brain function. Br Res Rev, 41, 79-87.

Takeda A., Ishiwatari S. and Okada S. (2000). Influence of transferrin on manganese uptake in rat brain. J Neurosci Res, 59, 542-552.

Takeda A., Sawashita J. and Okada S. (1995). Biological half-lives of zinc and manganese in rat brain. Brain Res, 695, 53-58.

Thompson K., Molina R. M., Donaghey T., Schwob J. E., Brain J. D. and Wessling-Resnick M. (2007). Olfactory uptake of manganese requires DMT1 and is enhanced by anemia. FASEB

J, 21, 223-230.

Tiffert T. and Lew V. L. (2001). Kinetics of inhibition of the plasma membrane calcium pump by vanadate in intact human red cells. Cell Calcium, 30, 337-342.

Triguero D., Buciak J. and Pardridge W. M. (1990). Capillary depletion method for quantification of blood-brain barrier transport of circulating peptides and plasma proteins. J Neurochem, 54, 1882-1888.

Tsukamoto T., Koizumi N. and Ninomiya R. (1987). [Manganese transfer from mothers to fetuses or sucklings during pregnancy and lactation]. Nippon Eiseigaku Zasshi, 42, 633-639.

Vandewalle B., Granier A. M., Peyrat J. P., Bonneterre J. and Lefebvre J. (1985). Transferrin receptors in cultured breast cancer cells. J Cancer Res Clin Oncol, 110, 71-76. 
Wadhwani K. C., Murphy V. A., Smith Q. R. and Rapoport S. I. (1992). Saturable transport of manganese(II) across blood-nerve barrier of rat peripheral nerve. Am J Physiol, 262, R284R288.

Wang X. S., Ong W. Y. and Connor J. R. (2001). A light and electron microscopic study of the iron transporter protein DMT-1 in the monkey cerebral neocortex and hippocampus. J Neurocytol, 30, 353-360.

Wedler F. C., Ley B. W. and Grippo A. A. (1989). Manganese(II) dynamics and distribution in glial cells cultured from chick cerebral cortex. Neurochem Res, 14, 1129-1135.

Wu L. J., Leenders A. G., Cooperman S., Meyron-Holtz E., Smith S., Land W., Tsai R. Y., Berger U. V., Sheng Z. H. and Rouault T. A. (2004). Expression of the iron transporter ferroportin in synaptic vesicles and the blood-brain barrier. Brain Res, 1001, 108-117.

Xiang M., Mohamalawari D. and Rao R. (2005). A novel isoform of the secretory pathway $\mathrm{Ca}^{2+}$, $\mathrm{Mn}\left({ }^{2+}\right)$-ATPase, hSPCA2, has unusual properties and is expressed in the brain. J Biol Chem, 280, 11608-11614.

Yokel R. A. (2006). Blood-brain barrier flux of aluminum, manganese, iron and other metals suspected to contribute to metal-induced neurodegeneration. J Alzheimer's Dis, 10, 223-253.

Yokel R. A. and Crossgrove J. S. (2004). Manganese toxicokinetics at the blood-brain barrier. Res Rep Health Eff Inst, 7-58; discussion 59-73.

Yokel R. A., Lasley S. M. and Dorman D. C. (2006). The speciation of metals in mammals influences thier toxicokinetics and toxicodynamics and therefore human health risk assessment. J Toxicol Environ Health, Part B, 9, 63-85.

Yokel R. A., Wilson M., Harris W. R. and Halestrap A. P. (2002). Aluminum citrate uptake by immortalized brain endothelial cells: Implications for its blood-brain barrier transport. Br Res, 930, 101-110. 
Table 1. Octanol/aqueous partition coefficient, predicted brain capillary diffusion rate $\left(P_{\text {diffusion }} X S\right)$ and brain $M n$ uptake into the parietal cortex $\left(K_{\text {in }}\right)$ for three representative $M n$ species, compared to two substances that very slowly diffuse across the BBB. From (Crossgrove et al. 2003).

\begin{tabular}{|c|c|c|c|}
\hline $\begin{array}{c}\text { Mn species or } \\
\text { diffusion marker }\end{array}$ & $\begin{array}{c}\text { Octanol/aqueous } \\
\text { partition coefficient }\end{array}$ & $\mathbf{P}_{\text {diffusion }} \mathbf{X ~ S ~ ( m l / s / g ) ~}$ & $\mathbf{K}_{\text {in }}(\mathbf{m l} / \mathbf{s} / \mathbf{g})^{\mathbf{c}}$ \\
\hline Mn $^{2+}$ ion & $3.6 \times 10^{-6}$ & $1.5 \times 10^{-5}$ & $13 \times 10^{-5}$ \\
\hline Mn citrate & $1.0 \times 10^{-5}$ & $1.7 \times 10^{-5}$ & $40 \times 10^{-5}$ \\
\hline Mn transferrin & $8 \times 10^{-4}$ a & $2.8 \times 10^{-5}$ & $12 \times 10^{-5}$ \\
\hline Sucrose & & $2.9 \times 10^{-5 b}$ & \\
\hline Dextran & $2.1 \times 10^{-3}$ & $4.8 \times 10^{-5}$ & \\
\hline
\end{tabular}

a The $\mathrm{D}_{\mathrm{o} / \mathrm{a}}$ of Mn Tf was corrected to account for the presence of unbound Mn (19\%), which was assumed to be the $\mathrm{Mn}^{2+}$ ion.

${ }^{b}$ Sucrose $P_{\text {diffusion }}$ was directly determined.

c The capillary depletion (enrichment) method, which separates brain tissue from capillary tissue (Triguero et al. 1990), was used to differentiate Mn reaching brain extracellular fluid from $\mathrm{Mn}$ adsorbed onto, or localized within, endothelial cells. The results showed 92,89 , and $75 \%$ of the $\mathrm{Mn}^{2+}$ ion, $\mathrm{Mn}$ citrate and $\mathrm{Mn}$ Tf were associated with the fraction composed of brain cells and brain extracellular fluid (Crossgrove et al. 2003). The results have been adjusted to account for the fraction of $\mathrm{Mn}$ associated with the endothelial cells. 